\title{
Public opinion on crime, punishment and the death penalty in Barbados
}

\section{Lynsey Black (D)}

Maynooth University, Ireland

\section{Lizzie Seal}

University of Sussex, England

\section{Florence Seemungal}

University of the West Indies Open Campus Faculty, Trinidad

\begin{abstract}
The bulk of extant research on public opinion on crime and punishment is focused on Global North nations. This article contributes a new perspective to the literature on punitivism by examining public opinion on crime, punishment and the death penalty in Barbados. The article presents insights from exploratory focus group research conducted in Barbados in 2017. These findings are particularly relevant as Barbadian lawmakers navigate reform of the nation's death penalty law. While the focus groups reveal anxieties that echo those identified in other jurisdictions, related to nostalgia for the past and concern regarding social order for instance, they also demonstrate the specific relevance of time and place. Using approaches from Caribbean Criminology and drawing on post-colonial perspectives, the article examines the context of views on punishment in Barbados, including perceptions of 'neo-colonial' interference and concerns about what can be lost in the process of 'progress'.
\end{abstract}

\section{Keywords}

Caribbean, death penalty, post-colonial, public opinion, punitivism, southern criminology

\section{Corresponding author:}




\section{Introduction}

This article draws on exploratory focus group research undertaken in Barbados in 2017 investigating attitudes to crime and punishment in a jurisdiction undergoing death penalty reform. ${ }^{1}$ The findings suggest that public opinion on the death penalty is complex and does not straightforwardly justify retention of the sanction. Findings identify familiar 'law and order' concerns, but also demonstrate the importance of the post-colonial frame in interpreting public attitudes to crime and punishment.

Barbados offers an alternative case study on punitiveness, often conceived as a 'global story' (Hutton, 2005: 252) despite research focusing on Western jurisdictions (Roberts et al., 2003). Barbados is a small island nation $\left(431 \mathrm{~km}^{2}\right)$ in the Eastern Caribbean, one of a group known as the Lesser Antilles. ${ }^{2}$ In 2018, the country's population was approximately 286,000 (UN Data, 2019a). Its colonial past and history of slavery distinguish it from Western developed countries. In the 1930s, Barbados 'was the most economically impoverished, racially divided, socially disadvantaged and politically conservative of the British West Indian colonies' (Chamberlain, 2010: 14). However, drawing on the 2017 Human Development Index, ${ }^{3}$ the United Nations Development Programme (UNDP, 2018) placed Barbados in the category of 'very high' human development. The UNDP notes significant gains made in life expectancy, schooling and gross national income per capita. Barbados represents a study of contrasts, coming from a recent history of disadvantage, to significant progress in living standards.

This article contributes to a growing Caribbean Criminology. Citing Pryce (1976), Cain (1996) outlined some first principles of Caribbean Criminology, including considering the lived Caribbean experience and challenging the predominance of universalising Western theory. This need to complicate the hegemonic embeddedness of theory emanating from the Global North is noted by proponents of southern theory (Connell, 2007) and southern criminology (Carrington et al., 2016). Cain (2000) problematised criminology's tendency to romanticize the 'Other' (Orientalism) and presumption that perspectives from the Global North are universally applicable to the Global South (Occidentalism), arguing that differences should be acknowledged, not fetishised. In the Caribbean context, it is necessary to consider criminal justice extending beyond national borders. Caribbean Criminology must consider monumental shifts of population resulting from slavery and indentured servitude (Agozino et al., 2009). Contemporaneously, drug trafficking and the war on drugs, both internationally felt phenomena, are significant influences on Caribbean crime and security (Bowling, 2010). Even within Caribbean Criminology, Barbados, a small nation with lower than regional average crime rates, has remained peripheral and under-studied.

The meanings of the death penalty cannot be separated from cultural or historical context. Girling et al. (2000) emphasised the need to consider time and place in perceptions of crime and punishment. As Barbados grapples with questions of how it should punish, this article provides a preliminary examination of the extent 
to which Barbadian citizens subscribe to punitivism. Talk on crime and punishment is symbolic, often reflecting generalised anxieties (Maruna and King, 2009); the symbolic nature of 'crime talk' is explored throughout as an expression of unease with social change. Although findings are drawn from a small study, the article suggests that there is space to re-imagine punishment in Barbados. However, the findings also point to ambivalence about human rights norms and a sense of the impact of modernity on Barbadian society.

\section{The death penalty in Barbados}

Until 2018, Barbados was one of the few countries globally to retain the mandatory death sentence for murder. This sanction was a creation of pre-independence English law, inherited on Barbadian independence in 1966. The mandatory sentence meant that, on conviction, there was no scope for judicial discretion or consideration of mitigating factors. The legal history of this sanction is tortuous, spanning continents and courts. Common to other former British colonies, following independence, the London-based Judicial Committee of the Privy Council (JCPC) became the final appellate court of Barbados. From the 1990s, the JCPC began to question the constitutionality of death sentence regimes in Caribbean countries. As a defiant response, Barbados enacted the Constitution (Amendment) Act 2002, an unsuccessful attempt to safeguard the death penalty from human rights arguments (Burnham, 2005). In 2005, partly in response to JCPC judgements, Barbados withdrew from its jurisdiction and adopted the Caribbean Court of Justice (CCJ) as its final court of appeal. ${ }^{4}$

However, despite its status (until recently) as an international outlier in its retention of the mandatory sentence, Barbados is de facto abolitionist, and there have been no executions since 1984 (Amnesty International, 2002). In 2017, although there were no new death sentences, 11 persons were under sentence of death (Amnesty International, 2018). From 2000 to 2017, 31 persons were death sentenced, 27 of whom had their sentences commuted to life imprisonment, 24 of whom were released from prison.

Most recently, in June 2018, the CCJ held that the mandatory death sentence in Barbados was unconstitutional. ${ }^{5}$ In doing so, the CCJ broke with the colonial past in its statement that (citing Robinson et al., 2015: 237-238): 'colonial laws and punishments are caught in a time warp continuing to exist in their primeval form, immune to the evolving understandings and effects of applicable fundamental rights'. The fact that this judgement articulated concerns about the legacy of colonialism is ironic in light of Barbados' hope that it would receive a more favourable hearing in a sympathetic Caribbean court, in contrast to the 'abolitionist' JCPC. However, the CCJ has tended to express agreement with JCPC jurisprudence. For instance, the 2006 case of Boyce and Joseph ${ }^{6}$ which upheld previous JCPC restrictions on the death penalty and which Cross (2014: 59) described as the 'de facto repeal' of the mandatory death sentence in Barbados. 
Such conflicting interpretations of historical legacy can be analysed from a postcolonial perspective. While the mandatory death sentence in Barbados was a colonial import, many in the focus groups considered the judgements of supranational courts and the JCPC as unwanted interference in a national matter, a feeling that can be interpreted as a rejection of neo-colonialism.

Following the 2018 CCJ judgement, the Offences Against the Person (Amendment) Act 2018 established a discretionary death penalty. This legislation introduced a list of aggravating factors, which, if present, empowers a judge to impose sentence of death for murder. The alternative is imprisonment for life. It remains to be seen how judges will respond to the newly discretionary regime.

\section{Researching populist punitiveness in the Caribbean}

There is little research into public opinion on crime and punishment in Barbados. Although exploratory in scope, the present study nevertheless offers rich qualitative insights into the importance of place and time in public attitudes to crime and punishment, and examines how the post-colonial context informs these attitudes. The little research that does exist is quantitative, and does not explore the deeper meanings of these matters for people in Barbados. A 2010 survey suggested that Barbados was less punitive than its Caribbean peers (Maguire and Johnson, 2015). Surveys from 1999, 2004 and 2010 measured public opinion on capital punishment and asked respondents to indicate whether they 'Support the Death Penalty', 'Don't Support the Death Penalty' or 'Don't Know'. Levels of support were $82 \%, 65 \%$ and $79 \%$, respectively (this $79 \%$ can be broken down to $50 \%$ in some cases of murder and $29 \%$ in all cases) (cited in Wickham, 2010). Our research reveals nuances within public attitudes. Although the research took place nine months before the 2018 CCJ judgement, it presents the context in which the ruling was made.

Punitive criminal justice policies are often legitimised through reference to public support. However, measures of support for such policies are problematic. Binary questions miss the complexity of opinion, something that focus groups can explore. Research carried out in Nordic countries, for example, concluded that 'propensities towards punitiveness seem to diminish with more information' (Balvig et al., 2015: 342). Research on capital punishment in Trinidad and Tobago has similarly found that the public are less punitive when presented with detailed case studies (Hood and Seemungal, 2011). Findings from Trinidad and Tobago are salient as, like Barbados, it retained and continues to impose the mandatory death sentence for murder post independence.

\section{Methodology}

The research investigated public opinion on crime and punishment in Barbados including particular focus on the death penalty. It was funded via a Higher Education Innovation Fund grant from the University of Sussex. The authors 
held two focus groups in Barbados in September 2017 with the support of the UNDP. Focus groups were an appropriate method for conducting exploratory research on a topic about which little is known. Two researchers acted as comoderators, guiding questioning, while another performed the role of assistant moderator, observing and note-taking. Participants were selected by nonrepresentative convenience sampling; recruitment was by online advertisement in Barbados Today, a national daily newspaper. ${ }^{7}$ Focus groups lasted 90 minutes, with 25 participants in total, 13 women and 12 men. This offered a suitable number 'to yield diversity in information' while avoiding too large a group 'where participants do not feel comfortable sharing their thoughts, opinions, beliefs, and experiences' (Onwuegbuzie et al., 2009: 3). The age range spanned 19 to 78, the mean age was 40.2 and the median was 46 (standard deviation of 16.1).

All the participants worked or studied and lived in Barbados, and the majority $(n=23)$ were Barbadian (one participant was from Jamaica and one participant from St. Vincent). Twenty-one participants identified as Black/Afro-Caribbean/ Afro-Barbadian (84\%), one participant identified as Mixed (4\%), one as White $(4 \%)$ and two did not answer this question (8\%). UN statistics from 2010 give ethnic data for Barbados as 92.4\% Black, 2.7\% White, 3.1\% Mixed and 1.3\% East Indian.

Participants' education (by highest level commenced) was recorded. Six participants $(24 \%)$ had commenced secondary education and $19(76 \%)$ had commenced tertiary education. Enrolment in tertiary education in Barbados was $65.43 \%$ in 2011 (UN Data, 2019b), although this figure hid disparity by gender (male enrolment was $40.33 \%$ while female enrolment was $90.58 \%$ ). This disparity was present in the sample (12 of 13 women had commenced tertiary education and only 7 of 12 men).

Participants were drawn from a wide range of livelihoods. There were four students, two retired persons, four persons working in the service industry, five in administrative roles and seven in professions. A further three were selfemployed. Of the 25 participants, two identified as having 'No religion', while the remaining 23 identified with Protestant Christianity (including Evangelical, Anglican and Pentecostal).

A schedule of questions was prepared in advance which offered a discussion guide. Participants were asked to discuss their views on crime in Barbados, to identify issues they felt were important and their views on the death penalty. They revealed considerable first-hand experience of the criminal justice system, through current or former professions. Participants also discussed experience of crime, either from acquaintances who had been through the criminal justice system as offenders, or through their own experiences of victimisation. Such an experience may have encouraged them to participate. The online notice read: 'Volunteers needed to participate in public discussion on crime and punishment in Barbados'.

An abridged transcript was prepared from initial listens to audio recordings, followed by the creation of a full transcript as this 'represents the most rigorous and time-intensive mode of analyzing data' (Onwuegbuzie et al., 2009: 4). The recordings were listened to at multiple stages throughout the process. We employed 
thematic analysis as developed by Braun and Clarke (2006: 79), 'a method for identifying, analysing and reporting patterns (themes) within data'. Thematic analysis is an organic and reflexive process, and repeated listens of the recordings allowed for greater immersion in the data. Transcripts were supplemented with additional observational data, as well as from audio cues in the recordings, such as moments of laughter. Manual coding was conducted, and codes were collated and shared between researchers to facilitate discussion about coding decisions. From the codes, themes were generated. These themes, or patterns of shared meaning, sought to understand how participants made sense of issues of crime and punishment.

As a piece of preliminary investigation, researchers focused primarily on semantic or 'surface' themes, such as concerns about crime. However, within these themes, more latent currents are highlighted, such as ambivalence to international human rights norms and the post-colonial context. The researchers interpreted the data with regard to the body of literature on public opinion on crime and punishment, and perspectives from post-colonial criminology.

\section{Findings}

\section{Themes}

Findings demonstrate participants' contradictory views on crime and punishment and perceptions of the realities of crime deeply entrenched in understandings of their political and cultural context. In initial introductions, participants identified themselves according to their parish, with some joking about crime rates there. The findings are therefore rooted in knowledge of place and the lived experience of Barbados. The following sections consider the perception of crime in Barbados, the associated causes and explanations, what this means for public opinion on the death penalty and the centrality of the post-colonial context in this regard. We identify three main themes, 'Loss of Community', 'Corporal Punishment' and 'Crime, Discipline and Deterrence', before reflecting on the post-colonial context. Themes were generated following an initial consensus among participants about 'Crime as a Salient Concern'.

In line with findings elsewhere, including Trinidad and Tobago, participants did not express support for the mandatory death sentence for murder (Hood and Seemungal, 2011). Hood and Hoyle (2009: 55) argue that 'with very few exceptions, those countries that still retain capital punishment have come to accept a good deal of the human rights case against the death penalty'. The findings reflect this to an extent; support for the death penalty was contingent support. However, throughout, the concept of 'human rights' was a point of contention. A minority of participants opposed the death penalty absolutely, for example, Jaquon's judgement that 'If you kill somebody for killing somebody, you endorse killing'. Beyond ideological objections, discussion demonstrated that many participants considered the death penalty an inappropriate punishment in many cases. One of the key 
concerns for those who supported the death penalty, in whatever form, was the view that Barbados was experiencing a crime problem.

\section{Crime as a salient concern}

There was consensus that crime was rising in Barbados. Andrew expressed a sense of crisis, in which crime played a significant part: 'we in our society, we have some serious problems'. Discussions were premised on this foundational assumption of a 'crime problem', evident in Jerome's statement that 'crime has grown throughout the years'. Once the 'social fact' (Fentress and Wickham, 1992) of crime was established, participants considered how this state of affairs had been reached.

In light of the statistics on crime in Barbados, it might seem that this diagnosis was misplaced. Maguire and Johnson (2015: 251) reference the "placid island of Barbados' in their study. There was awareness of crime in Barbados as low relative to other countries, for instance, Regina's admission that: 'I generally feel that Barbados is a much more safer place than where I come from [another Caribbean nation]'. However, 'objective' expressions of crime rates relative to other places are often meaningless for individuals who have emotive associations with crime in their area. For some locales, particularly those with traditionally low crime rates, any amount of crime is jarring (Girling et al., 2000). In this regard, many countries with low homicide rates demonstrate significant levels of death penalty support, for instance Japan and South Korea, with homicide rates of 0.28 and 0.72 per 100,000, respectively, in 2015 (UNODC, 2017). A report on crime in Barbados found that while the country compares favourably with its Caribbean neighbours, 'crimes against the person are issues of considerable and increasing concern among the Barbados population and require special attention in order to maintain adequate levels of perceived citizen security' (Bailey, 2016: 69). In 2015, Barbados' homicide rate was 10.91 per 100,000, low relative to 42.06 in Jamaica or 30.88 in Trinidad and Tobago (UNODC, 2017). However, it is significantly higher than the United Kingdom (0.99) and the United States (4.96). The literature on punitiveness has tended to focus on countries with medium to low levels of violent crime in global terms.

The concern expressed regarding crime may additionally be a feature of the small size of Barbados. There was a sense that questions of crime and punishment were not abstract or theoretical, but very real, and very raw. Personal connections with criminal justice matters are associated with what some considered the small, highly networked nature of Barbados; as Pauline stated, 'as we know, in Barbados society that small, small, small, small, small, if I thief this pen you done know by tomorrow morning'. King (2007) has cited the small and connected nature of Barbados society as one factor underpinning the relatively low crime rates on the island. However, this perception was generally not shared by participants.

Once the 'crime problem' had been diagnosed, participants generally turned to blaming and explaining (Girling et al., 2000). Their discussions were wide-ranging, but very definite themes can be identified. 


\section{Loss of community}

There was agreement on the loss of community, and a feeling that networks of knowledge had weakened. Participants differentiated their sense of the present with memories of community in years past. These views demonstrated how shared responses to crime were instrumental in generating a sense of community cohesion (Durkheim, 1893/1984). Participants argued that this was now absent in Barbados, and that there was no collective sense of responsibility. Shaneka framed this in relation to community and family: 'I guess in Bajan world, back then, would have been the community looks out for the children. But you don't see that now'. Many participants alluded to earlier community practices in which neighbours assumed parental roles. Wilfred, for example, recollected:

One time, a generation ago, I was watched by my neighbour, and everybody knew. I go back to my poor neighbourhood ... and everybody still remember me because people respect each other. It was the old-time community sort of thing.

Partly, loss of community was blamed on shifting family demographics, including a new generation of very young parents. Pauline assumed general agreement with her proposition that: 'you know how we work in Barbados today, everybody get children now early, a grandmother is now 35 years old, so we can't really depend heavily on the extended family, because things have changed.' Jaquon cited 'newly formed communities of total strangers', and a sense of isolation in modern Barbados: "“you don't talk to the people next door", you know, because them is the "thems" and we is the "we's".

These concerns suggest 'narratives of insecurity' (Hutton, 2005), associated with modernity. Insidious influences that undermined community were identified. Andrew, for one, commented that, 'You know there is a saying that it takes a village to raise a child, but you know today that it takes the television to raise your child'. Andrew went on to criticise the ambiguous morality of popular culture, which failed to impart instruction: 'Today, in order to be the star, you have to be the baddest guy'. Linked with notions of the deleterious effects of the modern world, there was concern regarding the prioritisation of material success:

when things become more instant and you don't have principles and proper culture, things you can do is you gonna struggle to go to a day to day job to make that money, especially when you see other people out there and things seem to be coming quicker, and faster, so you are always gonna be looking for faster ways to make that money. (Wesley)

Some lamented the decline of traditional restraints on modern, secular influences. The loss of communal values was explicitly associated by some participants with lapsed religious adherence, for example, by Peter who recalled pointedly, 'I remember learning scripture'. 
Lamentations over the loss of community networks contrast with King's (2007) characterisation of Barbados. However, claims about the failure of community structures in Barbados were not grounded in facts, nor, as Girling et al. (2000: 123) show, do such claims need the certitude of 'historical accuracy'. Instead, the past exists as a symbolic well from which individuals articulated fears for the future. As Fentress and Wickham (1992: 59) noted, the attraction of social memory is not that it is factually verifiable, but that it is stable 'at the level of shared meanings and remembered images'. These findings chime with existing research on public opinion on crime and punishment, suggesting some continuity across cultures, geography and time. Seal's (2017) historical work on attitudes to the death penalty in mid-twentieth century Britain revealed similar preoccupations to those expressed in present-day Barbados.

Sense of community loss (and, by extension, wider societal decline) was also shaped by national context, and participants alluded to a sense of 'growth' or 'development' specific to their knowledge of a changing Barbados. Peter felt that: 'as time has gone on, and people have seen us prosper, and so on, we got to the point where we wanted to kill the fatted calf'. Such observations were rooted in awareness of the impact of modernity on Barbadian life. Pauline explicitly related the present situation to a process of 'development':

over the years, we have done something as a people called 'grow', we grow, we do development, we talk about how we want to move on in life, our parents work in the cane fields, they don't want us to work in the cane fields, we don't want our children to work in the cane fields. So we looking at a series of growth. But while growth comes positively, it also comes negatively, and criminal and crime also grows.

Pauline went on to discuss the popularity of black market goods in Barbados. Comaroff and Comaroff (2006) consider that not only is the modernity of the postcolony viewed as counterfeit, criminal enterprise there is likewise perceived as linked to trade in counterfeit goods and illicit activity. The experience of modernity for persons living in Barbados offers an alternative to Global North perspectives that predominate.

In this context, Donna perceived a racialised application of criminal justice in Barbados' goal of economic prosperity:

Barbados is a tourism dependent country, and we have to look, appearance anyway, to people outside who are coming here to make us, so you see that a lot of the criminals, or the crimes we are talking about, affect people with this colour skin [motions to self].

Donna continued, remarking that 'the only people that you can see in [prison] as it was, are people like this [Afro-Caribbean]'. Donna's observation chimes with Thame's (2014) argument that in Barbados, the post-colonial prioritisation of order perpetuated a continued subordinate role for Afro-Caribbean persons. 
Likewise, Thame (2014: 24) also elaborates on development in Barbados as entailing strong commitment to a sense of order: 'Discourses around imperatives of citizenship therefore centred on the obligation of the Barbadian not to cause disturbance, to ensure that potential investors and tourists would not be scared away'.

As explored by Comaroff and Comaroff (2012: 117), modernity is many things, 'both a universal project and a host of specific, parochial emplacements'. In the case of post-colonial nations, there has been an assumption that modernity has brought endemic crime and lawlessness (Comaroff and Comaroff, 2006), an assumption that makes counter-perspectives essential. While Giddens (1990) conceptualised the ontological insecurity experienced alongside modernity from a Western perspective, it is notable that participants articulated 'nostalgia for ways of life that are disappearing' (Giddens, 1990: 137). This nostalgia was sometimes associated directly with views on the death penalty. Sean emphasised now in explaining his conditional support for the death penalty, because 'that is the Barbados that we live in right now'. The role of punishment in bolstering community resilience recalls Durkheim's view of punishment as necessary to defend moral order. Participants related the imposition of punishment to community wellbeing. On this point, Garland (1990: 43) writes that individual offences must be punished ... because of the ramifications such violations might have at the level of the moral order itself'. The perceived decline of community was explicitly linked to a failure to punish law-breaking. Nostalgia enabled expression of generalised feelings of community disintegration.

\section{Corporal punishment}

For many, loss of community mirrored a reduced capacity for discipline and a corresponding need for order. This reflects Thame's (2014) view that in the decades after independence, successive Barbadian governments sought to maintain the hierarchical order that had existed prior to independence. Throughout, participants referred to the importance of physical chastisement as essential to this aim of maintaining order. As Andrew viewed it, 'if you go down the road and you misbehave, next day so-and-so would give you two lashes and send you home, and you dare not tell your parents because you would get two more'. Corporal punishment remains a live issue in Barbados, a subject of frequent discussion in Assembly debates and media commentary. In a 2009 CADRES survey, 54\% supported corporal punishment in schools, and 75\% supported its use in the home. This is also an issue of interest for the UN, for instance, the UNCRC (2015: 32) acknowledged that 'The government in Barbados has been faced with significant and prolonged difficulty in changing the public's attitude towards corporal punishment'.

Discussion of corporal punishment took the form of criticism of human rights. This criticism also included discussion of the death penalty, irritation with procedural safeguards in the courts and hindered police capacity to act. Wilfred articulated this frustration with regard to children: 'Their mother are your age and they 
can think to themselves, you can't talk to my child, and it starts as simple as that'. This frustration went beyond the community, to the ability of teachers to physically discipline pupils, as Kay articulated it: 'I can't lash you and you have no respect for me because you know I can't lash you'.

The question of whether communities have the right to physically chastise children can be escalated to questions regarding society's right to execute offenders. The modern curtailments on both corporal and capital punishments were worrying trends for some participants. These views can be related to modern penal sensibilities and the belief among policy-makers that 'corporal punishments are a fact of history' and offensive in a 'civilised nation' (Garland, 1990: 241, 242). The notion of the 'civilised nation' is particularly pertinent in the Barbadian context, in light of participants' resistance to human rights norms, and the sense of these as part of 'development'. The question of bodily punishment in Barbados is therefore more recent, and more vexed, than in many Western democracies. In 1992, the Barbados Court of Appeal held that use of the cat-o'-nine-tails was unconstitutional. ${ }^{8}$ This judgement came in response to a 1991 case in which the judge called for the revival of flogging (Antoine, 1992). The taboo nature of the infliction of bodily pain in modern penality led Wesley to suggest more 'humane' methods of execution:

in terms of growth and how it might be perceived, hanging in Barbados was the death penalty. I don't understand why you can't move to lethal injection [some clapping] or electrocution, if it less humane, fine, it is done in all parts of the world, I don't know if they are signed on to anything but if hanging is such a big deal, fine, scrap the hanging, lethal injection, electrifying ... electrocution, electric chair.

Wesley identified the influence of human rights throughout contemporary Barbados society, linking it to the death penalty, as well as perceived leniency for juveniles: 'the magistrate will say he's only 15, and give him some counselling for two weeks and send him back to school'. A failure of discipline (and disciplinarians) acted as a metaphor for much concern. Failure to discipline children was an allegory for societal ills. As Jaquon stated, 'the hands-off approach let things get out of hand, and is responsible for a lot of things that we seeing going on'. Throughout, themes of discipline and order were dominant. Effective, occasionally severe, criminal justice sanctions were considered necessary in the context of these concerns.

\section{Crime, discipline and deterrence}

It was clear from discussions that the wider community felt themselves to be 'invested' in crime and punishment (Durkheim, 1893/1984). Participants repeatedly considered the ways in which the Barbadian criminal justice system was at fault, manifest particularly in relation to the courts, which were maligned as not fit for purpose, pronounced by Peter to be 'inefficient, laggardly and slow'. Garland (1990: 74) argues the passing of sentence is the apogee of societal 
condemnation: 'The public's concern with punishment, and the rise and fall of "passionate reactions", tend to centre around the deployment of the available sanctions - who gets what sentence? - rather than with the details of what goes in penal institutions'. In the research, this was expressed in real concerns about the inadequacies of the courts, which meant that the catharsis of sentencing was too often denied. In addition to problems of delay, participants were critical of what they saw as an excessively lenient system, Regina's comment was typical of many: 'persons are no longer really afraid that there will be a penalty to something that a crime they have committed because, like you say, they go to the courts and get bail'. Participants held an instinctive belief in the deterrent value of punishment, and many were critical of permissiveness bred by an overly 'soft' response. Heather felt strongly that 'if you don't send a message, if you keep giving people the light sentences, it will not change'.

While there was exasperation with the courts, there was some admiration for the police: 'because to be honest when you look at the hurdles that they have to go through to bring some person to justice, it's very hard' (Andrew). Sympathy flowed from the belief that police effectiveness was curtailed, 'because their hands are tied by what laws and by what so-called rights criminal have' (Wilfred), while Kent explicitly referenced 'all the ratifications, and all these things that the country will have signed to and what does that mean and how it affects you as a police officer'.

These views resonate with Packer's (1968) crime control model as preferable over a due process model. This zero-sum conception of rights came into play when considering the appropriateness of death as punishment. Wilfred argued strongly for an 'us' and 'them' conception of who rights protect, and who they imperil: 'now we have magistrates on the bench who deal with the rights of the criminal, which is the $1 \% \ldots$ who is going to protect the $99 \%$ ?' Against this, the obstacle course of due process presents 'formidable impediments to carrying the accused any further along in the process' (Packer, 1968: 162). Participants criticised these impediments as checks on action and evasions of justice. As Wu et al. (2011) note, criminal justice orientation has not been explicitly studied as a correlate for death penalty support. In the research, it was identified as an underlying consideration for participants.

In the view of human rights as a zero-sum game, offenders were considered the winners. As Heather asked: 'we talking about human rights, what about the rest of the victims and the families'. This concern was evident in discussions of the death penalty. Some identified restrictions imposed on criminal justice in Barbados by international bodies such as the JCPC. There was a sense of resistance at the continued interference that threatened national sovereignty. On this point, participants cited the role of 'International pressure' (Edmund) and 'Treaties and things that we signed... when we say that we are developing our people' (Pauline).

When participants did express support for the death penalty, a range of justifications were articulated, such as deterrence ('Maybe if we say, execute one person, it just might send a shockwave through the public,' Elisa) and retribution ('people say that death penalty is not a deterrent, I agree, it is a punishment for 
god's sake! It's not meant to be a deterrent,' Heather). Participants also highlighted the dissonance between retaining the death penalty and Barbados' status as abolitionist de facto. The failure to execute condemned persons was considered an encouragement to criminality by some, including Wilfred: 'having death penalty and not enforcing death penalty is where the problem is'. In the context of a 'crime problem', some expressed support for the death penalty as a necessary sanction, such as Andrew, who believed that: 'capital punishment is one of the things that we will have to use'. The death penalty was therefore tied to a sense of protection against societal decline. As Seal (2017: 19) found in her mid-century British work, capital punishment becomes a perceived 'barricade against social breakdown and an essential means of ensuring the state's monopoly on violence'.

The specific context of the death penalty in Barbados, and its salience as an issue in public debate, had created awareness of the international instruments to which the country was subject, as well as relevant legal judgements. Participants were often well versed in this recent history, and cited the Pratt and Morgan case in particular (a JCPC judgement which held that a person may not be executed after a period of 5 years from conviction ${ }^{9}$ ). This contrasts with findings elsewhere which demonstrate that knowledge about the death penalty is low, for instance in Japan, where little information is provided by government (Johnson, 2006). The Marshall hypothesis has sought to test whether providing more information on the death penalty diminishes public support (Burgason and Pazzani, 2014). From our participants' generally well-informed opinions on the death penalty, it does not appear that increasing knowledge necessarily correlates with decreasing support. However, it is over 30 years since the last executions in Barbados, and only a certain demographic remembers the death sentence being carried out.

\section{Post-colonial contexts}

The foregoing themes have repeatedly touched on the specific context of Barbados; crucially, these findings can be interpreted through a post-colonial frame. Barbados became a British colony in 1627, achieving independence in 1966 (Beckles, 2006). For much of this period, until the 1830s, Barbados was a slave society. The literature has clearly demonstrated the violence of the colony, and the use of violence and the law in ways that emphasised racial difference. ${ }^{10}$ As Bogues (2002: 13) notes, colonial governance in the Caribbean was 'structured around brute force and command'. Under Gould's (2003) conception of 'zones of law' and 'zones of violence', brutality that would have provoked disquiet in the metropole was accepted as necessary by colonial authorities operating in 'zones of violence'.

That criminal justice policy in this context was deployed in specifically racialised ways is evident in the fact that much of the Caribbean criminal justice legislation of the nineteenth century was introduced following the abolition of slavery. These laws were enacted with the purpose of imposing repressive state control on the formerly enslaved. For white planters, the end of slavery demanded a re-tooled criminal justice system. In Barbados following abolition, the numbers of capital 
statutes increased significantly. Levy (cited in Harris, 2017: 41) records the passing of 'An Act for the Prevention and Punishment of Malicious Injuries to Property', 'An Act for the Punishment and Prevention of Larceny' and 'An Act for the Prevention and Punishment of Offences Against the Person'. Tellingly, the categorisation of property offences as capital offences occurred at a time when the death penalty was being abolished for these crimes in Britain. Anderson (2015) suggests that while capital punishment was not routinely used in the Caribbean in the nineteenth century, the threat remained a crucial tool for colonial control. As Sherman (2009) has outlined, the death penalty stood as one weapon in an arsenal of repressive practices that she terms a 'coercive network'.

State-imposed criminal justice therefore represented a specific function, temporally situated, tied to the perceived needs of post-slavery society and the imperative of maintaining order. As Thame (2014) has argued, with regard to Barbados, this need to maintain and enforce order became a postindependence imperative for Barbadian governments as well. Despite the colonial origins of the death penalty, and echoing state prioritisation of order and discipline after independence, focus group participants viewed the death penalty as a Barbadian matter, rather than a colonial imposition. Along with the mandatory death sentence, other preserved colonial practices or prohibitions included (for a time) punishment by flogging and (still) the criminalisation of same-sex sex. Robinson (2019) has recently argued that despite their colonial origins, these laws have assumed the status of 'loved law', and have generated an affective intensity among citizens of Caribbean nations. Longevity has gifted to these laws the imprimatur of sovereignty, and ownership, rather than invoking a sense of such law as alien to Caribbean society.

Maurer (1997) has noted the centrality of law in the creation of 'nation' and 'people', and the indigenization of law in the post-colonial context to achieve these aims. The indigenization of law in the Caribbean occurred in tandem with an ethos of political conservatism. As Robinson et al. (2015: 48) write, 'Modern Caribbean constitutionalism, especially in the independent states, has been marked by strong traditionalism, highly valuing the continuity of political institutions and practices that developed during the colonial period'. They claim that this was particularly so with Barbados, where its leaders viewed continuity as a way of demonstrating political maturity. When Barbados achieved independence, although the new constitution espoused rights protections based on European models, the same constitution also protected existing colonial punishments (Robinson et al., 2015: 51). In effect, this enshrined laws that marked earlier efforts of colonial control, laws that were deployed to 'emphasise racial difference and to maintain racial subordination during the colonial period' (Robinson et al., 2015: 51). Thame (2014: 14) writes that, following independence, 'As a function of the Caribbean state's concern with its survival, it sought legitimacy, control and power over its own populations'. In Barbados, the death penalty was therefore re-fashioned as a sovereign symbol to be protected as a manifestation of order. 


\section{Conclusion}

This article draws on focus group research to explore the meanings of crime, punishment and the death penalty in Barbados. The findings highlight the need to locate such meanings within their political and cultural context, and the culturally specific meanings of death as punishment (Garland, 2002). Such meanings are geographically situated and demonstrate the relevance of time and place. As the majority of research on public opinion on the death penalty is American, the necessity for conducting research in other jurisdictions that retain this sanction is clear.

The findings can contribute to Caribbean Criminology, and the need to consider transnational and historical influences. This is evident in the post-colonial form of the criminal justice system in Barbados, and the legacy of the mandatory death sentence. An important contribution of the research is identifying 'human rights' as unwanted outside interference, perceived as a form of neo-colonialism. This specific circumstance informs Barbados' sense of contemporary engagement with international political norms. As noted by participants, the 'development' experienced by the country, recorded as an objective measure by the UNDP, also entails requirement of human rights compliance, about which many were ambivalent. Throughout, participants spoke with frustration about the imposition of standards from the international community. At a national level, the move from the JCPC to the CCJ is the clearest example of this position.

The meanings participants assigned to crime and punishment were strikingly similar to concerns identified by Seal (2017) in her research on public opinion in mid-century Britain, and even earlier in Victorian discourses on crime and punishment (Pearson, 1983). Converging with extant work on modernity, the findings indicate feelings of nostalgia for the past, and a fear for the deterioration of society. Our discussion shows how the expression of similar crime concerns and sentiments about punishment in different times and places is underpinned by diverse histories and contexts. Attention to these contexts is necessary in order to trace how similar sentiments can have different roots. In Barbados, post-coloniality and the indigenization of capital punishment underlies feeling about the death penalty.

\section{Acknowledgements}

The authors would like to thank the United Nations Development Programme in Barbados, particularly Michelle Brathwaite, the National Human Rights Officer, and Stephen O'Malley, the UN Resident Co-ordinator. The authors would also like to thank the Max Planck Institute for European Legal History, Frankfurt, for providing the space to work on aspects of the article. The authors also thank the reviewers for their generosity and constructive feedback.

\section{Funding}

This research was made possible through a Higher Education Innovation Fund (HEIF) award from the University of Sussex, and a College of Social Sciences and Law seed funding award from University College Dublin. 


\section{ORCID iD}

Lynsey Black (D) https://orcid.org/0000-0002-2852-7328

\section{Notes}

1. A current EU-funded project seeks to build civil society engagement in Barbados to further shape reform (University of the West Indies, 2018).

2. Its nearest neighbours are St Vincent and the Grenadines, St Lucia, Dominica, Grenada, and Trinidad and Tobago.

3. The Human Development Index is based on life expectancy, access to knowledge and standard of living.

4. The CCJ was established in 2005 .

5. Nervais v The Queen (2018) CCJ 19 and Severin v The Queen (2018) CCJ 19.

6. Attorney General of Barbados v Boyce and Joseph (2006) CCJ 3.

7. Internet users represent $79.5 \%$ of the Barbados population. This is comparable to United States (76.2\%), UK (94.8\%) and Ireland (85\%) (UNDP, 2018).

8. Hobbs and Mitchell $v$ R (1992) 46 WIR 42.

9. Pratt v Attorney-General for Jamaica (1993) UKPC 1.

10. See Anderson's (2015) discussion of the refusal of 'benefit of clergy' to those capitally convicted before the slave courts in Barbados.

\section{References}

Agozino B, Bowling B, Ward E, et al. (2009) Guns, crime and social order in the West Indies. Criminology \& Criminal Justice 9(3): 287-305.

Amnesty International (2002) Barbados: Proposed executions could constitute murder. AMR 15/002/2002.

Amnesty International (2018) Death sentences and executions 2017. ACT 50/7955/ 2018.

Anderson C (2015) Execution and its aftermath in the nineteenth-century British Empire. In: Ward (ed) Global History of Executions and the Criminal Corpse. London: Palgrave, pp.170-198.

Antoine RMB (1992) The reintroduction of the cat-o'-nine-tails in Barbados: A tale of woe. Caribbean Law Review 1: 26.

Bailey C (2016) Crime and Violence in Barbados. IDB Series on Crime and Violence in the Caribbean, Inter-American Development Bank, IDB-TN-1059.

Balvig F, Gunnlaugsson H, Jerre K, et al. (2015) The public sense of justice: A study of attitudes towards punishment. European Journal of Criminology 12(3): $342-361$.

Beckles H (2006) A History of Barbados: From Amerindian Settlement to Caribbean Single Market. Cambridge: Cambridge University Press.

Bogues A (2002) Politics, nation and postcolony: Caribbean inflections. Small Axe 6(1): 1-30.

Bowling B (2010) Policing the Caribbean: Transnational Security Co-Operation in Practice. Oxford: Oxford University Press.

Braun V and Clarke V (2006) Using thematic analysis in psychology. Qualitative Research in Psychology 3(2): 77-101. 
Burgason KA and Pazzani L (2014) The death penalty: A multi-level analysis of public opinion. American Journal of Criminal Justice 39: 818-838.

Burnham MA (2005) Saving constitutional rights from judicial scrutiny: The savings clause in the law of the Commonwealth Caribbean. University of Miami InterAmerican Law Review 36(2): 249-269.

CADRES (2009) Corporal punishment and other major education issues in Barbados. Barbados Union of Teachers/UNICEF.

Cain M (1996) Crime and criminology in the Caribbean - An introduction. Caribbean Quarterly 42(2/3): v-xx.

Cain M (2000) Orientalism, occidentalism and the sociology of crime. British Journal of Criminology 40(2): 239-260.

Carrington K, Hogg R and Sozzo M (2016) Southern criminology. British Journal of Criminology 56(1): 1-20.

Chamberlain M (2010) Empire and Nation-Building in the Caribbean: Barbados, 19371966. Manchester: Manchester University Press.

Comaroff J and Comaroff JL (eds) (2006) Law and Disorder in the Postcolony. Chicago: University of Chicago Press.

Comaroff J and Comaroff JL (2012) Theory from the South: Or, how Euro-America is evolving toward Africa. Anthropological Forum 22(2): 113-131.

Connell R (2007) Southern Theory: The Global Dynamics of Knowledge in Social Science. Crow's Nest: Allen and Unwin.

Cross JE (2014) A matter of discretion: The de facto abolition of the mandatory death penalty in Barbados - A study of the Boyce and Joseph cases. Inter-American Law Review 46: 39-59.

Durkheim E (1893/1984) The Division of Labour in Society. Basingstoke: Macmillan.

Fentress J and Wickham C (1992) Social Memory. Oxford: Blackwell.

Garland D (1990) Punishment and Modern Society. Clarendon: Oxford.

Garland D (2002) The cultural uses of capital punishment. Punishment \& Society 4(4): $459-487$.

Giddens A (1990) The Consequences of Modernity. Oxford: Polity Press.

Girling E, Loader I and Sparks R (2000) Crime and Social Change in Middle England: Questions of Order in an English Town. London: Routledge.

Gould EH (2003) Zones of law, zones of violence: The legal geography of the British Atlantic, circa 1772. William and Mary Quarterly 60(3): 471-510.

Harris DP (2017) Punishing the Black Body: Marking Social and Racial Structures in Barbados and Jamaica. Athens: University of Georgia Press.

Hood R and Hoyle C (2009) Abolishing the death penalty worldwide: The impact of a "new dynamic". Crime and Justice 38(1): 1-63.

Hood R and Seemungal F (2011) Public Opinion on the Mandatory Death Penalty in Trinidad. London: Death Penalty Project/Oxford Centre for Criminology.

Hutton N (2005) Beyond populist punitiveness. Punishment \& Society 7(3): 243-258.

Johnson DT (2006) Where the state kills in secret: Capital punishment in Japan. Punishment \& Society 8(3): 251-285.

King W (2007) Paradise lost? Crime in the Caribbean: A comparison of Barbados and Jamaica. In: Deosaran R (ed) Crime, Delinquency and Justice. Kingston: Ian Randle. 
Maguire E and Johnson D (2015) The structure of public opinion on crime policy: Evidence from seven Caribbean nations. Punishment \& Society 17(4): 502-530.

Maruna S and King A (2009) Is a Conservative just a Liberal who has been mugged? Exploring the origins of punitive views. Punishment \& Society 11(2): 147-169.

Maurer B (1997) Recharting the Caribbean: Land, Law and Citizenship in the British Virgin Islands. Ann Arbor: University of Michigan Press.

Onwuegbuzie AJ, Dickinson WB, Leech NL, et al. (2009) A qualitative framework for collecting and analyzing data in focus group research. International Journal of Qualitative Methods 8(3): 1-21.

Packer HL (1968) The Limits of the Criminal Sanction. Redwood: Stanford University Press.

Pearson G (1983) Hooligan: A History of Respectable Fear. London: Palgrave Macmillan.

Pryce K (1976) Towards a Caribbean criminology. Caribbean Issues 11(2): 2-3.

Roberts JV, Stalans LJ, Indemaur D, et al. (2003) Penal Populism and Public Opinion: Lessons from Five Countries. New York: Oxford University Press.

Robinson T (2019) Loving Law: Criminalization and Decriminalization of Same-sex Sex in the Anglophone Caribbean', Thursday 30th May 2019, Law and Society Association, Washington DC. Unpublished conference paper provided to authors in personal correspondence.

Robinson T, Bulkan A and Saunders A (2015) Fundamentals of Caribbean Constitution Law. London: Sweet and Maxwell.

Seal L (2017) Perceptions of safety, fear and social change in the public's pro-death penalty discourse in mid-twentieth century Britain. Crime, History \& Societies 21(1): 13-34.

Sherman TC (2009) Tensions of colonial punishment: Perspectives on recent developments in the study of coercive networks in Asia, Africa and the Caribbean. History Compass 7(3): 659-677.

Thame M (2014) Disciplining the nation: Considering the privileging of order over freedom in postcolonial Jamaica and Barbados. Social and Economic Studies 63(2): 1-29.

United Nations Committee on the Rights of the Child (2015) Second Periodic Report on Barbados. CRC/C/BRB/2.

UN Data (2019a) UN Data (UN Statistics Division). http://data.un.org/en/index.html (accessed 9 October 2019).

UN Data (2019b) Sustainable development goals (UNESCO Institute for Statistics) http://uis.unesco.org/country/BB (accessed 9 October 2019).

United Nations Development Programme (2018) Human Development Indices and Indicators: 2018. http://hdr.undp.org/en/countries/profiles/BRB (accessed 9 October 2019).

United Nations Office on Drugs and Crime (2017) Statistics and Data (Homicide Data by Countries. Available at: https://dataunodc.un.org/GSH_app (accessed 9 October 2019).

University of the West Indies (2018) EU-funded project on the death penalty. 13 September. https://www.cavehill.uwi.edu/Law/news-notices/eu-funded-project-onthe-death-penalty.aspx (accessed 9 October 2019).

Wickham P (2010) To hang or not to hang. Nation News, 12 September, http://www. nationnews.com/nationnews/news/31568/hang-hang (accessed 9 October 2019). 
Wu Y, Sun IY and Wu Z (2011) Support for the death penalty: Chinese and American college students compared. Punishment and Society 13(3): 354-376.

Lynsey Black is a lecturer/assistant professor in Criminology at Maynooth University. Her current research examines gender and punishment in Ireland, and post-colonial perspectives on the death penalty. Her first monograph, Women, Murder and the Death Penalty in Ireland, 1922-64, will be published by Manchester University Press in 2021.

Lizzie Seal is reader in Criminology at University of Sussex. Her previous publications are on capital punishment, historical criminology, cultural criminology, transgression and gender representations of women who kill. She is the author of Capital Punishment in Twentieth-Century Britain: Audience, Justice, Memory (2014) and, with Maggie O’Neill, Imaginative Criminology (2019).

Florence Seemungal, BSc Sociology (UWI); PhD Cognitive Psychology (University of Southampton), is a former research officer at the Centre for Criminology, University of Oxford, and current Visiting Academic, Centre for Socio-Legal Studies, University of Oxford. 